\title{
Soil sulfur fractions dynamics and distribution in a tropical grass pasture amended with nitrogen and sulfur fertilizers
}

\author{
Fabiana Schmidt1, Fabiano Daniel De Bona1*, Cristiane Prezotto Silveira1, and Francisco Antonio Monteiro1 \\ 1 Soil Science Department, "Luiz de Queiroz" College of Agriculture, University of São Paulo, 13418-900 Piracicaba - SP, Brazil
}

\begin{abstract}
Soil sulfur (S) partitioning among the various pools and changes in tropical pasture ecosystems remain poorly understood. Our study aimed to investigate the dynamics and distribution of soil S fractions in an 8-year-old signal grass (Brachiaria decumbens Stapf.) pasture fertilized with nitrogen $(\mathrm{N})$ and $\mathrm{S}$. A factorial combination of two $\mathrm{N}$ rates $\left(0\right.$ and $600 \mathrm{~kg} \mathrm{~N} \mathrm{ha}^{-1} \mathrm{y}^{-1}$, as $\mathrm{NH}_{4} \mathrm{NO}_{3}$ ) and two $S$ rates ( 0 and $60 \mathrm{~kg} \mathrm{~S} \mathrm{ha}^{-1} \mathrm{y}^{-1}$, as gypsum) were applied to signal grass pastures during $2 \mathrm{y}$. Cattle grazing was controlled during the experimental period. Organic $S$ was the major $S$ pool found in the tropical pasture soil, and represented $97 \%$ to $99 \%$ of total S content. Among the organic $S$ fractions, residual $S$ was the most abundant (42\% to $67 \%$ of total $S$ ), followed by ester-bonded S (19\% to $42 \%)$, and C-bonded S (11\% to $19 \%)$. Plant-available inorganic $\mathrm{SO}_{4}-\mathrm{S}$ concentrations were very low, even for the treatments receiving $S$ fertilizers. Low inorganic $\mathrm{SO}_{4}$-S stocks suggest that $\mathrm{S}$ losses may play a major role in $\mathrm{S}$ dynamics of sandy tropical soils. Nitrogen and $S$ additions affected forage yield, $S$ plant uptake, and organic $S$ fractions in the soil. Among the various soil fractions, residual $\mathrm{S}$ showed the greatest changes in response to $\mathrm{N}$ and $S$ fertilization. Soil organic $S$ increased in plots fertilized with $S$ following the residual $S$ fraction increment $(16.6 \%$ to $34.8 \%)$. Soils cultivated without $\mathrm{N}$ and $\mathrm{S}$ fertilization showed a decrease in all soil organic $S$ fractions.
\end{abstract}

Key words: Brachiaria decumbens / fertilization / sulfur fractionation / tropical soil

Accepted June 2, 2011

\section{Introduction}

Sulfur (S) is an essential element for plants, and the soil constitutes the major S source (Scherer, 2001). In the soil, S can be found in different forms and fractions. Inorganic $\mathrm{SO}_{4}$-S (S adsorbed in colloids, dissolved in the soil solution, and precipitated $\mathrm{SO}_{4}-\mathrm{S}$ ) is readily available for plants and represents $\approx$ $5 \%$ of the total soil S (Tabatabai, 2005). Soil organic S can be associated with ester-bonded S (C-O-S, C-N-S, and C-S-S), C-bonded $\mathrm{S}$ reducible by Raney-Ni (C-S, mainly amino acids), and residual $S$. Each soil organic $S$ fraction exhibits distinct labilities and mineralization potentials (McGill and Cole, 1981; Ghani et al., 1993).

The availability of $S$ to plants is controlled by numerous factors that affect the dynamics of $S$ fractions in the soil. Similarly, the inorganic $\mathrm{SO}_{4}$-S concentration in the soil depends on plant $\mathrm{S}$ uptake (Hu et al., 2002), mineral weathering, inputs via atmospheric deposition, losses via leaching (Kost et al., 2008), the use of sulfate fertilizers, and the biochemical and biological mineralization/immobilization processes of the organic S fractions (McGill and Cole, 1981). Changes in the soil inorganic $S$ pool play a major role in $S$ dynamics because it can impact the transformation of organic $S$ fractions in the soil (McGill and Cole, 1981; Ghani et al., 1993; Kertesz and Mirleau, 2004).

Previous studies have examined the dynamics of soil S fractions under forest (Vannier and Guillet, 1994), cropland (Yang

\footnotetext{
* Correspondence: F. D. De Bona;
}

e-mail: debonasolos@yahoo.com.br et al., 2007), and grassland (Nguyen and Goh, 1992) in temperate regions. However, limited information about the dynamics of $S$ pools is available for tropical soils (Neptune et al., 1975; Stanko-Golden and Fitzgerald, 1991; Solomon et al., 2001). This is particularly true for native or cultivated pasture systems, which constitute a major land use in South America (particularly the Brazilian Cerrado zone) and Africa (savannah).

Approximately $55 \%$ of the 172 million ha of grassland in Brazil consists of Brachiaria. These grasses are highly productive rhizomatous perennial plants that can respond well to $S$ and $\mathrm{N}$ fertilization (De Bona and Monteiro, 2010). The forage responses to $\mathrm{S}$ and $\mathrm{N}$ fertilization have been extensively reported for other species such as bahiagrass (Paspalum notatum Fluegge): Kalmbacher et al. (2005); oat (Avena sativa L.): Wang et al. (2002); and ryegrass (Lolium sp.): Mathot et al. (2008).

All nutritional factors that regulate the growth of Brachiaria plants are expected to directly or indirectly affect the status and transformations of the soil $S$ fractions. The turnover of $S$ is enhanced by the plant uptake of inorganic $\mathrm{SO}_{4}-\mathrm{S}$ and the return to the soil as organic $S$ through dead leaves and roots. In addition, biological processes (e.g., mineralization and immobilization) that regulate soil $\mathrm{S}$ dynamics can be stimulated by the exudates of living plant roots (Nguyen, 2003). 
Because $\mathrm{N}$ and $\mathrm{S}$ are closely related in the plant-soil system (protein synthesis and soil organic matter [SOM] constituents), the availability of both nutrients is expected to affect the dynamics of the soil $\mathrm{S}$ pools. As soil $\mathrm{S}$ fractions have different chemical natures and labilities, it is also expected that $\mathrm{S}$ organic pools change distinctly in response to $\mathrm{N}$ input and pasture growth. Thus, the objective of this study was to investigate the dynamics and distribution of soil $S$ fractions in an established Brachiaria pasture receiving $\mathrm{N}$ and $\mathrm{S}$ fertilization.

\section{Material and methods}

\subsection{Site description}

The study area (pasture) was located in an agricultural farm near the city of Piracicaba, SP, Brazil $\left(22^{\circ} 46^{\prime} \mathrm{S}\right.$; $47^{\circ} 57^{\prime} \mathrm{W}$; $600 \mathrm{~m}$ asl). According to Köppen's classification, the climate of Piracicaba is classified as Cwa type (humid mesothermal climate, with hot and rainy summers and chilly to mild dry winters). The average air temperature, rainfall, and relative humidity were $21.2^{\circ} \mathrm{C}, 1253 \mathrm{~mm} \mathrm{y}^{-1}$, and $74 \%$, respectively. The dry season extends from April to September. During the spring/summer wet season (October to March), intense rainfall events are common, and several reach intensities of $50 \mathrm{~mm} \mathrm{~h}^{-1}$ or more.

The study pasture area was established in October 1997 and consisted of a pure stand of signal grass (Brachiaria decumbens Stapf.). These $\mathrm{C}_{4}$ plants are characterized morphologically as low-growing rhizomatous and stoloniferous perennial grasses that exhibit a decumbent growth habit, bright green moderately hairy leaves, and an extensive root system. Since its establishment, the pasture has been continuously grazed by beef cattle and has received no fertilizer.

The soil is classified as an Entisol according to the USDA Soil Taxonomy (Soil Survey Staff, 1999). The chemical characteristics of soil samples collected from depth of 0 to $0.20 \mathrm{~m}$ before the beginning of the fertilization experiment in October 2005 were the following: $P$ extracted by resin ( $P$ resin) $=3.5 \mathrm{mg} \mathrm{kg}^{-1}, \mathrm{~K}=46.8 \mathrm{mg} \mathrm{kg}^{-1}, \mathrm{Ca}=106.3 \mathrm{mg} \mathrm{kg}^{-1}$, $\mathrm{Mg}=37.1 \mathrm{mg} \mathrm{kg}^{-1}, \mathrm{Al}=71.7 \mathrm{mg} \mathrm{kg}^{-1}, \mathrm{H}$ plus $\mathrm{Al}(\mathrm{H}+\mathrm{Al})=$
$21.5 \mathrm{mmol}_{\mathrm{c}} \mathrm{dm}^{-3}$, sum of bases $=8.1 \mathrm{mmol}_{\mathrm{c}} \mathrm{dm}^{-3}$, cationexchange capacity $\left(\right.$ CEC) $=29.5 \mathrm{mmol}_{\mathrm{c}} \mathrm{dm}^{-3}$, and base saturation $(B S)=26.8 \%$. Additional physical and chemical soil parameters, including $S$ fractions contents, were detailed in layers within the 0 to $0.40 \mathrm{~m}$ soil profile (Tab. 1).

\subsection{Fertilization experiment}

The experimental site was fenced in October 2005 to exclude cattle grazing. Prior to treatment applications, the plots received $600 \mathrm{~kg} \mathrm{ha}^{-1}$ of dolomitic limestone. The size of each plot was $5 \mathrm{~m} \times 8 \mathrm{~m}$. The experiment was set in a randomized block design with three replications. Four factorial combinations of $\mathrm{N}\left(0\right.$ and $\left.600 \mathrm{~kg} \mathrm{~N} \mathrm{ha}^{-1}\right)$ and $\mathrm{S}\left(0\right.$ and $\left.60 \mathrm{~kg} \mathrm{~S} \mathrm{ha}^{-1}\right)$ rates were studied. Nitrogen and $\mathrm{S}$ were supplied as $\mathrm{NH}_{4} \mathrm{NO}_{3}$ $(30 \% \mathrm{~N})$ and gypsum (15\% S), respectively. Fertilizers were applied annually at the beginning of the wet season (October, November, and December). Phosphorus, K, and micronutrients were applied each year using $30 \mathrm{~kg} \mathrm{ha}^{-1} \mathrm{y}^{-1}$ of triple superphosphate, $30 \mathrm{~kg} \mathrm{ha}^{-1} \mathrm{y}^{-1}$ of $\mathrm{KCl}$, and $30 \mathrm{~kg} \mathrm{ha}^{-1} \mathrm{y}^{-1}$ of fritted trace elements (FTE $\mathrm{Br} 16)$, respectively. The application rates of $P, K$, and micronutrients were based on soil tests and regional fertilizer recommendations (Boletim 100, 1996) for optimal pasture production with high dry-matter yield. Both dolomite and fertilizers were surface-applied in a single application.

The climatic conditions during the experimental period are shown in Fig. 1. Experimental plots were grazed at either 5- (wet season) or 8-week (dry season) intervals. For each grazing event, animals (beef cattle) were allowed to graze for $\approx 24 \mathrm{~h}$. Grazing reduced the sward height to $\approx 0.10 \mathrm{~m}$.

\subsection{Forage and soil sampling}

Forage evaluation was performed before each grazing event. The accumulated forage was estimated for each treatment using a $1.0 \mathrm{~m} \times 0.25 \mathrm{~m}$ quadrat. Quadrats were harvested to a $5 \mathrm{~cm}$ stubble height. Shoot tissue was oven-dried at $65^{\circ} \mathrm{C}$ prior to analysis.

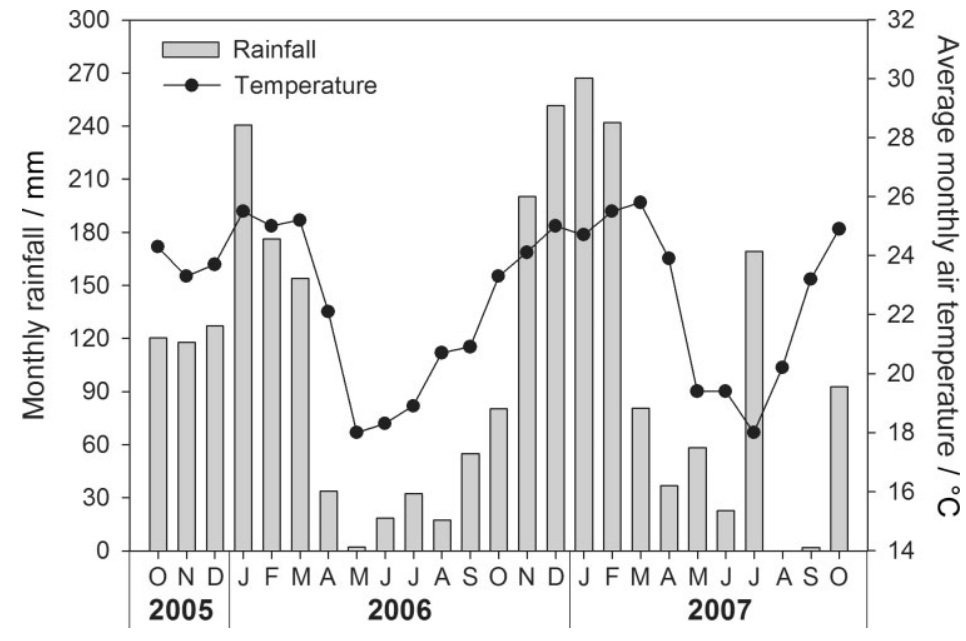

Figure 1: Monthly rainfall and average air temperature during the 2 y fertilization experiment. 
Table 1: Initial soil chemical and physical characterization. Values in parentheses represent standard errors of the mean $(n=3)$.

\begin{tabular}{|c|c|c|c|c|c|c|c|}
\hline \multirow[t]{2}{*}{ Depth / m } & \multicolumn{7}{|c|}{ Chemical parameters } \\
\hline & $\mathrm{pH} \mathrm{CaCl}{ }_{2}$ & $\begin{array}{l}\text { C org. } \\
/ \mathrm{g} \mathrm{kg}^{-1}\end{array}$ & $\begin{array}{l}\mathrm{N} \text { total } \\
/ \mathrm{g} \mathrm{kg}^{-1}\end{array}$ & \multicolumn{2}{|c|}{$C: N$} & $C: S$ & $N: S$ \\
\hline $0-0.10$ & $5.06(0.23)$ & $16.8(1.87)$ & $0.53(0.02)$ & \multicolumn{2}{|c|}{$53.9(4.40)$} & $336.3(7.60)$ & $6.35(0.66)$ \\
\hline $0.10-0.20$ & $4.97(0.07)$ & $16.9(1.95)$ & $0.58(0.11)$ & \multicolumn{2}{|c|}{$51.3(3.41)$} & $375.5(70.1)$ & $7.38(1.37)$ \\
\hline $0.20-0.30$ & $4.98(0.29)$ & $11.6(2.60)$ & $0.46(0.11)$ & \multicolumn{2}{|c|}{$44.1(3.01)$} & $300.8(65.5)$ & $6.83(1.51)$ \\
\hline $0.30-0.40$ & $5.13(0.31)$ & $11.2(1.57)$ & $0.45(0.06)$ & \multicolumn{2}{|c|}{$43.2(4.52)$} & $283.9(29.3)$ & $6.85(1.35)$ \\
\hline \multirow[t]{2}{*}{ Depth / m } & \multicolumn{7}{|c|}{ Physical parameters } \\
\hline & $\begin{array}{l}\text { bulk density } \\
/ \mathrm{kg} \mathrm{dm}^{-3}\end{array}$ & texture & $\begin{array}{l}\text { sand } \\
/ \mathrm{g} \mathrm{kg}^{-1}\end{array}$ & $\begin{array}{l}\text { loam } \\
/ \mathrm{g} \mathrm{kg}^{-1}\end{array}$ & $\begin{array}{l}\text { clay } \\
/ \mathrm{g} \mathrm{kg}^{-1}\end{array}$ & $\begin{array}{l}\mathrm{Fe}_{\circ} \\
/ \%\end{array}$ & $\begin{array}{l}\mathrm{Fe}_{\mathrm{d}} \\
/ \%\end{array}$ \\
\hline $0-0.10$ & $1.48(0.04)$ & Sand & $914(10.2)$ & $36(2.30)$ & $50(1.34)$ & $0.04(0.01)$ & $0.83(0.08)$ \\
\hline $0.10-0.20$ & $1.53(0.04)$ & Sand & $920(12.3)$ & $30(1.34)$ & $50(2.20)$ & $0.04(0.01)$ & $0.89(0.07)$ \\
\hline $0.20-0.30$ & $1.54(0.02)$ & Sand & $919(11.2)$ & $31(1.41)$ & $50(1.56)$ & $0.05(0.01)$ & $0.93(0.05)$ \\
\hline $0.30-0.40$ & $1.55(0.03)$ & Sand & $935(13.6)$ & $14(2.11)$ & $52(2.31)$ & $0.06(0.01)$ & $0.90(0.04)$ \\
\hline \multirow[t]{2}{*}{ Depth / m } & \multicolumn{7}{|c|}{ Sulfur parameters } \\
\hline & $\begin{array}{l}\text { inorganic } \mathrm{SO}_{4}-\mathrm{S} \\
/ \mathrm{mg} \mathrm{kg}^{-1}\end{array}$ & $\begin{array}{l}\text { ester-bonded S } \\
/ \mathrm{mg} \mathrm{kg}^{-1}\end{array}$ & $\begin{array}{l}\text { carbon-bonded S } \\
/ \mathrm{mg} \mathrm{kg}^{-1}\end{array}$ & $\begin{array}{l}\text { residual S / } \\
\mathrm{mg} \mathrm{kg}^{-1}\end{array}$ & $\begin{array}{l}\text { organic S } \\
/ \mathrm{mg} \mathrm{kg}^{-1}\end{array}$ & $\begin{array}{l}\text { total S } \\
/ \mathrm{mg} \mathrm{kg}^{-1}\end{array}$ & $\begin{array}{l}\text { total S stock } \\
/ \mathrm{kg} \mathrm{ha}^{-1}\end{array}$ \\
\hline $0-0.10$ & $1.28(0.11)$ & $25.9(0.72)$ & $12.9(0.39)$ & $46.1(11.1)$ & $84.9(11.6)$ & $86.5(11.6)$ & $127.6(17.1)$ \\
\hline $0.10-0.20$ & $1.02(0.18)$ & $24.3(1.97)$ & $13.4(0.61)$ & $42.1(12.5)$ & 79.8 (11.9) & $80.9(12.0)$ & $123.8(18.4)$ \\
\hline $0.20-0.30$ & $1.18(0.39)$ & $21.3(3.05)$ & $13.2(0.29)$ & $31.2(1.20)$ & $65.7(3.90)$ & $66.9(4.30)$ & $103.3(6.60)$ \\
\hline $0.30-0.40$ & $1.13(0.23)$ & $18.9(3.75)$ & $14.0(0.96)$ & $35.5(8.90)$ & $68.4(11.5)$ & $69.5(11.7)$ & $107.4(18.1)$ \\
\hline
\end{tabular}

Soil samples were collected at the initiation (October 2005) and the end (October 2007) of the fertilization experiment. In each plot, three soil cores (length $=0.60 \mathrm{~m}, \varnothing=0.08 \mathrm{~m}$ ) were collected from soil depths of 0 to $0.10 \mathrm{~m}, 0.10$ to $0.20 \mathrm{~m}, 0.20$ to $0.30 \mathrm{~m}$, and 0.30 to $0.40 \mathrm{~m}$. Soil samples were air-dried, sieved through a $2 \mathrm{~mm}$ mesh sieve, and then milled. The soil bulk density of all soil samples was also determined at the beginning of (Tab. 1) and after the 2-year experiment.

\subsection{Chemical analysis}

The total $\mathrm{S}$ in the plant shoots was determined using the wet digestion procedure $\left(\mathrm{HNO}_{3}\right.$ and $\left.\mathrm{HClO}_{4}\right)$; $\mathrm{S}$ concentrations in the extracts were quantified by turbidimetry (Lisle et al., 1994).

Soil S fractionation was performed according to the method described by Tabatabai (1982). The following four soil S fractions were obtained: (1) inorganic $\mathrm{SO}_{4}-\mathrm{S}$ (mineral $\mathrm{S}$ in the soil solution and adsorbed), (2) ester-bonded S (HI-reducible S minus inorganic $\mathrm{SO}_{4}-\mathrm{S}$ ), (3) $\mathrm{C}$-bonded $\mathrm{S}$ (organic $\mathrm{S}$ reducible by Raney-Ni alloy), and (4) residual S (organic S not reducible either by $\mathrm{HI}$ or Raney-Ni alloy). Inorganic $\mathrm{SO}_{4}-\mathrm{S}$ was extracted with $0.01 \mathrm{~mol} \mathrm{~L}^{-1} \mathrm{Ca}\left(\mathrm{H}_{2} \mathrm{PO}_{4}\right)_{2}$ solution and quantified by means of turbidimetry (Tabatabai and Bremner, 1970). The HI-reducible $\mathrm{S}$ was determined by reduction with a solution of $\mathrm{HI}, \mathrm{H}_{3} \mathrm{PO}_{2}$, and $\mathrm{CH}_{2} \mathrm{O}_{2}$ in an adapted distillation apparatus according to Johnson and Nishita (1952). The $\mathrm{H}_{2} \mathrm{~S}$ formed was entrapped in an absorbing solution of $\mathrm{NaOAc}$ $\mathrm{Zn}(\mathrm{OAc})_{2}$ and quantified by spectrophotometry at $670 \mathrm{~nm}$ after the addition of solutions of $\mathrm{N}, \mathrm{N}$-dimethyl-p-phenylenediamine sulfate $\left[\left(\mathrm{CH}_{3}\right)_{2} \mathrm{NC}_{6} \mathrm{H}_{4} \mathrm{NH}_{2} \cdot \mathrm{H}_{2} \mathrm{SO}_{4}\right]$ and ferric ammo- nium sulfate $\left[\mathrm{Fe}_{2}\left(\mathrm{SO}_{4}\right)_{3}\left(\mathrm{NH}_{4}\right)_{2} \mathrm{SO}_{4}\right]$ for the development of the methylene blue color. Carbon-bonded $\mathrm{S}$ was initially reduced to $\mathrm{H}_{2} \mathrm{~S}$ by the Raney-Ni alloy in an alkaline medium in the modified apparatus of Johnson and Nishita (1952) and was then entrapped and quantified as described for the HI-reducible S. The ester-bonded $S$ fraction was calculated as the difference between the $\mathrm{HI}$-reducible $\mathrm{S}$ and the inorganic $\mathrm{SO}_{4}-\mathrm{S}$.

The total $\mathrm{S}$ in the soil was determined using the acid digestion procedure $\left(\mathrm{HNO}_{3}, \mathrm{HClO}_{4}\right.$, and $\left.\mathrm{HCl}\right)$ (Tabatabai, 1982). Determination of the $\mathrm{S}$ concentration in the extract followed the same protocol as described for the HI-reducible $S$ pool. Organic $S$ was estimated by the difference between total soil $\mathrm{S}$ and inorganic $\mathrm{SO}_{4}-\mathrm{S}$. Similarly, the residual $\mathrm{S}$ fraction was calculated based on the difference between the total $S$ and the HI-reducible $\mathrm{S}$ and Raney-Ni-reducible $\mathrm{S}$. Although the wet-chemical method of the $S$ fractionation procedure does not identify the chemical nature of residual $S$, previous reports indicated that this fraction consists of oxidized Cbonded $S$ such as sulfones, sulfoxides, and/or sulfonates (Stanko and Fitzgerald, 1990; Prietzel et al., 2003). Soil S stocks were calculated by using the S-concentration and soilbulk-density data.

\subsection{Data analysis}

Soil and plant data were processed using Microsoft Excel 2007 (Microsoft, Redmond, WA, USA) and/or Sigma Plot 10.0 (Systat Software, San Jose, CA, USA) software packages. Data are reported as mean \pm one standard error of the mean. 


\section{Results}

Nitrogen and $S$ fertilization affected Brachiaria decumbens production (Fig. 2A). A greater forage yield (17.1 Mg ha-1 $\mathrm{y}^{-1}$ ) was observed when $\mathrm{N}$ and $\mathrm{S}$ were supplied together at rates of 600 and $60 \mathrm{~kg} \mathrm{ha}^{-1} \mathrm{y}^{-1}$, respectively. The addition of $\mathrm{N}$ alone increased shoot dry-matter yield by $\approx 50 \%$ (9.15 to 13.8 $\mathrm{Mg} \mathrm{ha}^{-1} \mathrm{y}^{-1}$ ), whereas the addition of $\mathrm{S}$ fertilization alone had no effect on forage production.

The primary balance between $S$ input (fertilizers) and $S$ extraction (plant production) showed that S-fertilized soils, with and without an additional $\mathrm{N}$ supply, received $\mathrm{S}$ increments of $\approx 40$ and $50 \mathrm{~kg} \mathrm{~S} \mathrm{ha}^{-1} \mathrm{y}^{-1}$, respectively (Fig. 2B). In

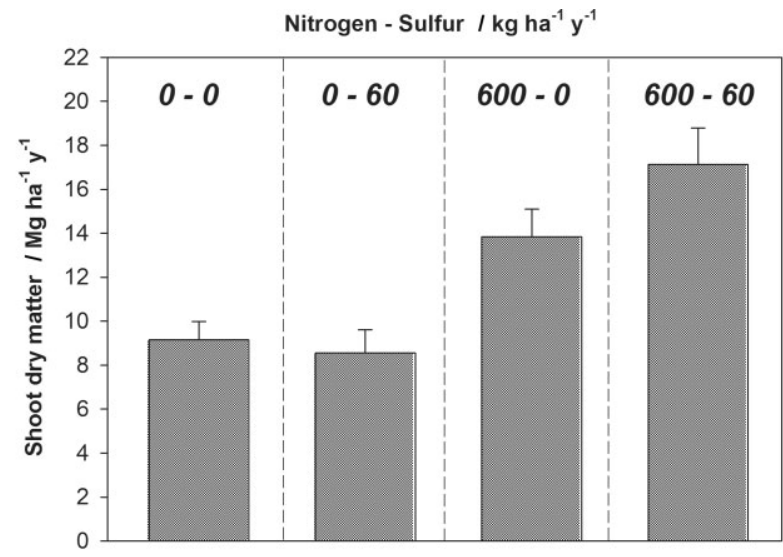

(A)

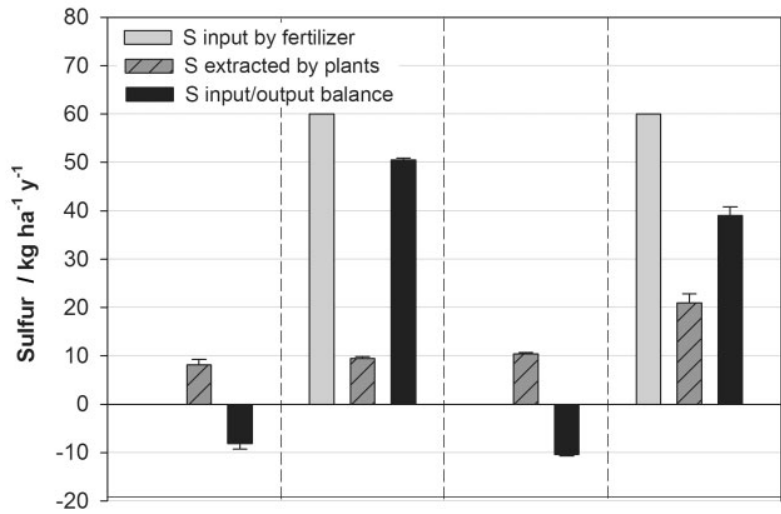

(B)

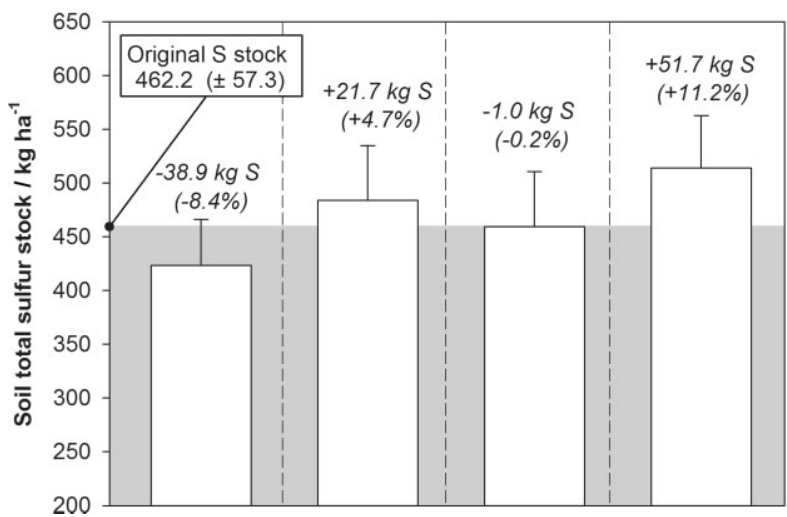

(C)

Figure 2: Shoot production of Brachiaria decumbens $(\mathrm{A})$, primary soil $S$ input/output balance (B), and soil total S stocks $(0-0.40 \mathrm{~m})(\mathrm{C})$ in a pastureland amended with $\mathrm{N}$ and $\mathrm{S}$ fertilizations during the $2 \mathrm{y}$ period. Error bars represent standard errors of the mean. contrast, treatments receiving no $S$ fertilization decreased the total soil $S$ by $\approx 9 \mathrm{~kg} \mathrm{~S} \mathrm{ha}^{-1} \mathrm{y}^{-1}$. Similarly, the soil $S$ stock at the 0 to $0.40 \mathrm{~m}$ soil depth at the end of the $2 \mathrm{y}$ fertilization experiment decreased in treatments receiving no $S$ addition (mean of $19.9 \mathrm{~kg} \mathrm{ha}^{-1}$ ); however, treatments receiving $S$ fertilizer increased the soil $S$ pool (mean of $36.7 \mathrm{~kg} \mathrm{ha}^{-1}$ ) (Fig. 2C).

Changes in the total soil S content as the result of plant production and S fertilization (Fig. 2) were mainly due to changes in the organic $S$ fraction content $\left(-41.6\right.$ to $\left.+48.2 \mathrm{~kg} \mathrm{ha}^{-1}\right)$ (Fig. 3). Relatively small changes in $S$ stocks due to plant accumulation and $S$ fertilization were observed in the soil inorganic $\mathrm{SO}_{4}-\mathrm{S}$ fraction (2.8 to $3.5 \mathrm{~kg} \mathrm{ha}^{-1}$ ). The soil organic $\mathrm{S}$ increased in plots fertilized with $\mathrm{S}$ following the residual $\mathrm{S}$ fraction increment (16.6\% to $34.8 \%$ ). Soils cultivated without $\mathrm{N}$ and $\mathrm{S}$ fertilization showed a decrease in all soil organic $\mathrm{S}$ fractions. Regardless of $\mathrm{S}$ treatment, plots receiving $\mathrm{N}$ showed a decrease in the ester-bonded $S$ fraction of $\approx 12 \%$. Similarly, the C-bonded S content decreased in all treatments $(-15.9 \%$ to $-34.4 \%)$.

After 2 y of $\mathrm{N}$ and $\mathrm{S}$ application, relatively larger differences among $S$ fraction contents were found in samples from soil depth of 0 to $0.10 \mathrm{~m}$ (Fig. 4). Plots receiving $\mathrm{N}$ fertilizer (with or without the addition of $S$ ) showed an increase in total $S$ (73.9 to $98.3 \mathrm{mg} \mathrm{kg}^{-1}$ ), organic $S$ (72.4 to $96.8 \mathrm{mg} \mathrm{kg}^{-1}$ ), and residual $\mathrm{S}$ (36.7 to $54.2 \mathrm{mg} \mathrm{kg}^{-1}$ ) concentrations at the 0 to $0.10 \mathrm{~m}$ soil depth (Fig. $4 \mathrm{~A}, 4 \mathrm{~B}$, and $4 \mathrm{C}$, respectively). In contrast, the ester-bonded $S$ concentration (27.4 to $20.6 \mathrm{mg} \mathrm{kg}^{-1}$ ) at the same soil depth was lower in the $\mathrm{N}$-fertilized plots than in the plots receiving no $\mathrm{N}$ (Fig. 4E). With the exception of treatments receiving exclusively $60 \mathrm{~kg} \mathrm{~S} \mathrm{ha-1}^{-1} \mathrm{y}^{-1}$, all plots showed slight decreases in total $S$, organic $S$, residual $S$, and C-bonded S concentrations in deeper soil layers (Fig. 4A, 4B, $4 \mathrm{C}$, and $4 \mathrm{~F}$, respectively). Despite the use of high $S$ fertilization, very low sulfate concentrations were found in all soil layers and ranged from 0.85 to $1.29 \mathrm{mg} \mathrm{kg}^{-1}$ (Fig. 4D).

Averaged across all treatments, organic S accounted for $97 \%$ to $99 \%$ of the total $S$ found in the $0-0.40 \mathrm{~m}$ soil profile (Fig. 5). Among the organic $S$ fractions, residual $S$ was the most abundant fraction (42\% to $67 \%$ ) in soil, followed in order by ester-bonded S (19\% to $42 \%)$ and C-bonded S (11\% to $19 \%)$. Nitrogen and $S$ additions affected the distribution of organic $S$ fractions in samples from soil depth of 0 to $0.10 \mathrm{~m}$ (Fig. 5A). Plots receiving no $\mathrm{N}$ showed greater soil esterbonded $S$ and lower residual $S$ proportions to total $S$ compared to $\mathrm{N}$-fertilized plots. Although the $\mathrm{C}$-bonded $\mathrm{S}$ fraction changed during the 2 y experiment (Fig. 3), relatively small differences in concentration (Fig. 4F) and proportions to total $S$ (Fig. 5) were observed across the various soil depths.

\section{Discussion}

Highly weathered soils are commonly used as pastures in tropical zones. In such agroecosystems, the dynamics of essential elements are closely related to the rainfall regime and soil organic compartment, which is controlled by living plants through nutrient-turnover processes and the activity of microorganisms. Our experimental site represents a typical highly 


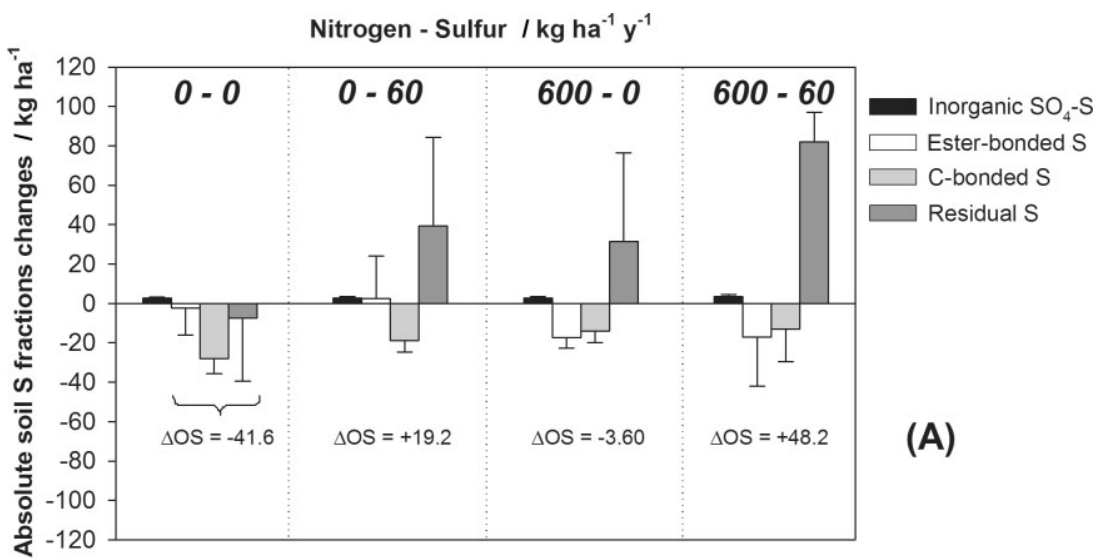

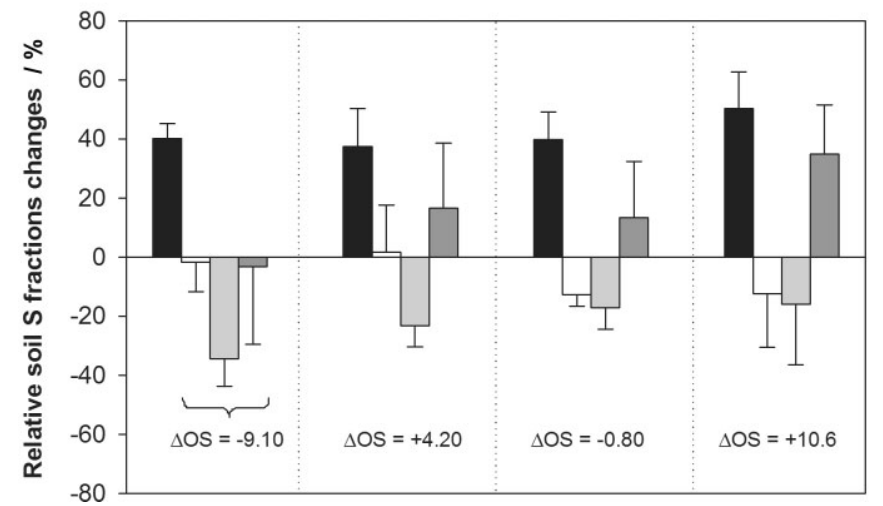

weathered soil with low organic matter, very coarse texture (> $90 \%$ sand) and low content of Fe oxides (Tab. 1). Sulfur and $\mathrm{N}$ limitations on plant growth were evident, so it was expected that the addition of both nutrients would be likely to increase signal grass production (Fig. 2A). Similarly to previous studies of different grasses (Kalmbacher et al., 2005; Salvagiotti et al., 2009; De Bona and Monteiro, 2010), our data show that plant responses to $\mathrm{S}$ application enhanced $\mathrm{N}$ use efficiency.

The fate of $S$ that was added and not used by plants (Fig. 2B) may include pathways such as incorporation into organic fractions (biochemical or biological transformations), adsorption onto soil colloids (inorganic $\mathrm{SO}_{4}-\mathrm{S}$ ), and/or leaching in the soil profile (McGill and Cole, 1981). Low inorganic $\mathrm{SO}_{4}-\mathrm{S}$ throughout the profile $(0-0.40 \mathrm{~m})$ of S-fertilized and unfertilized plots (Fig. 4D) and the soil S stocks determined prior to and after the 2 y study (Fig. 2C) suggested that $S$ losses (likely via sulfate leaching) may play a major role in the $S$ dynamics of sandy tropical soils (Tab. 1). Sulfur losses via sulfate leaching are expected to be very intense in environmental conditions similar to those of our experimental site. Soils that exhibit a very low anion-exchange capacity (low soil organic matter and oxides content) (Tab. 1) associated with intensive rainfall events during the spring/summer wet season (Fig. 1) likely promoted very high S losses. Therefore, agricultural practices that can enhance plant yields and $S$ accumulation, such as the use $\mathrm{S}$ and $\mathrm{N}$ fertilizer mixes (Fig. 2A), are recommended to minimize $S$ losses from the soil. Our data showed that plots fertilized with a combination of $\mathrm{N}$ and $\mathrm{S}$ (600 and $60 \mathrm{~kg} \mathrm{ha}^{-1} \mathrm{y}^{-1}$ of $\mathrm{N}$ and $\mathrm{S}$, respectively) exhibited a greater forage production and soil S stock than plots fertilized solely with $S$ (60 kg ha-1 $\mathrm{y}^{-1} \mathrm{~S}$ ) (Fig. 2). In the absence of $\mathrm{N}, \mathrm{S}$ not taken up by the forage plant was subjected to leaching and likely accumulated in the deeper $(>0.40 \mathrm{~m})$ soil layers.

The results indicate that regardless of the S-fertilization regimen, the role of inorganic $\mathrm{SO}_{4}-\mathrm{S}$ in forage production was relatively less important than the organic $S$ fractions (Tab. 1, Figs. 4 and 5). The data show a decrease in organic $S$ stock in plots receiving no $\mathrm{S}$ amendment (Fig. 3). Certainly, organic $\mathrm{S}$ acts as an inorganic $\mathrm{SO}_{4}-\mathrm{S}$ sink through immobilization or incorporation processes mediated by microorganisms, soil enzymes, and/or plant residue turnover (McGill and Cole, 1981). With respect to the soil organic S pool, results indicate that residual $S$ plays an important role because this fraction comprises more than half of the organic $S$ pool and is more sensitive to changes in plant responses and fertilization treatments. Plots receiving $\mathrm{N}$ fertilization show an accumulation of residual $S$ at the $0-0.10 \mathrm{~m}$ soil depth (Fig. $4 \mathrm{C}$ ) that was likely due to increases in shoot (residue) and root production (40\% increases). The combination of $\mathrm{N}$ and $\mathrm{S}$ increased the residual S fraction by $\approx 80 \mathrm{~kg} \mathrm{ha}^{-1}$ of S (or $35 \%$ ), whereas depletion of this $S$ pool was observed in the unfertilized plots (Fig. 3). According to other studies, the residual S consists of C-bonded S (which is more oxidized than the C-bonded S fraction determined by the Raney-Ni alloy method [basically $S$ amino acids]) and is composed of sulfones, sulfoxides, and/or sulfonates (Stanko and Fitzgerald, 1990; Prietzel et al., 2003). McGill and Cole (1981) reported that the residual $S$ is associated with soil humus and can be formed by biological 

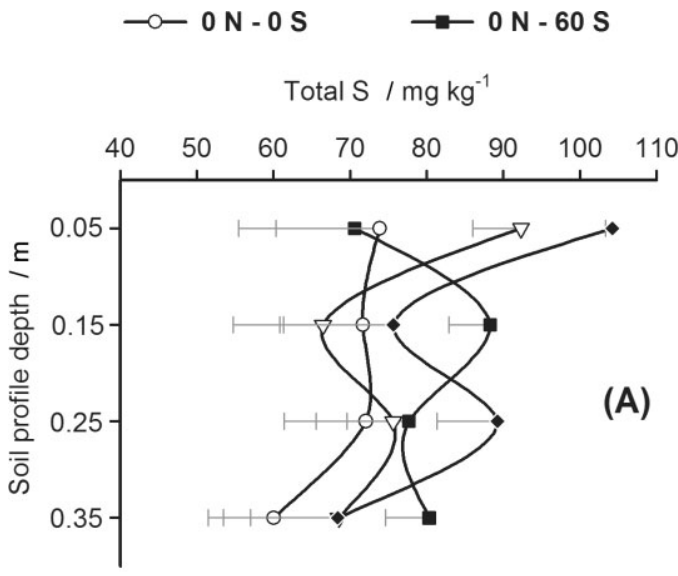

Organic $\mathrm{S} / \mathrm{mg} \mathrm{kg}^{-1}$

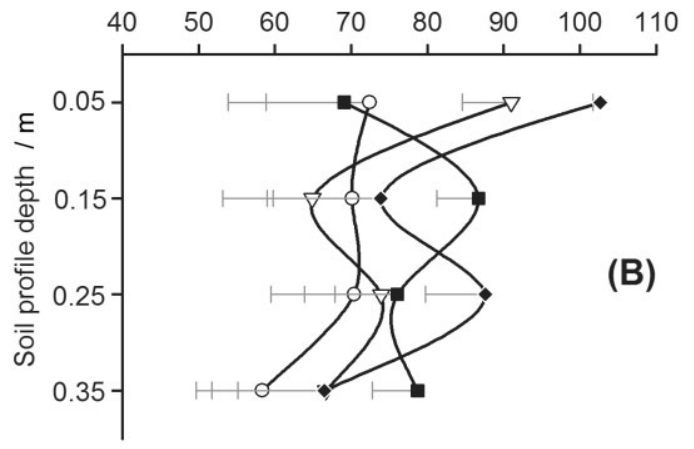

Residual S / $\mathrm{mg} \mathrm{kg}^{-1}$

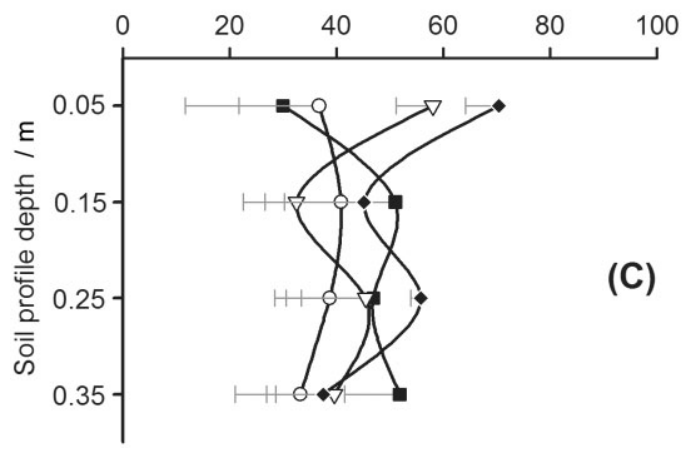

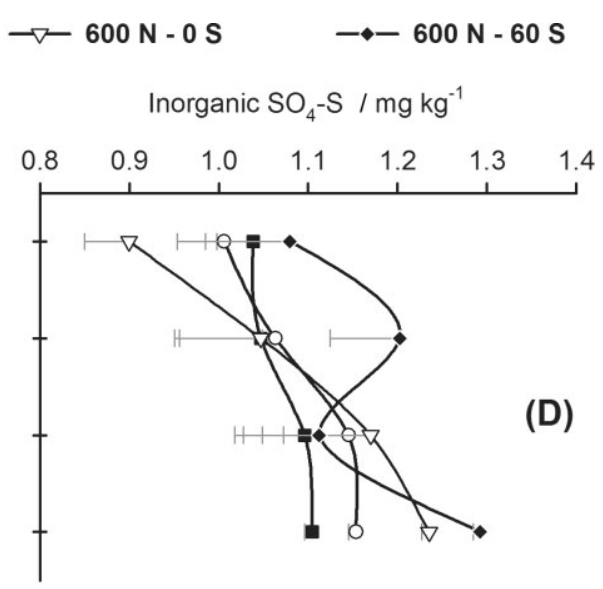

Ester-bonded S / $\mathrm{mg} \mathrm{kg}^{-1}$

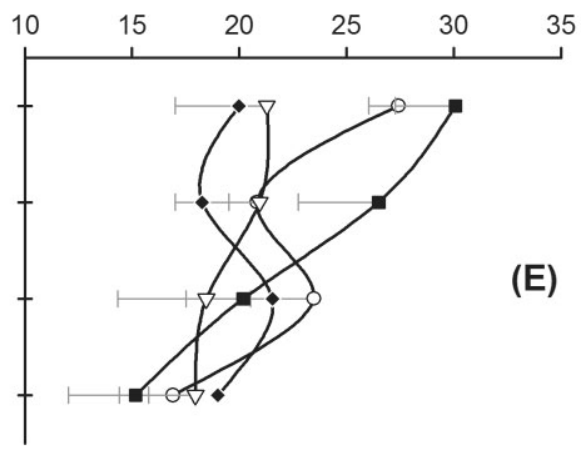

C-bonded S / $\mathrm{mg} \mathrm{kg}^{-1}$

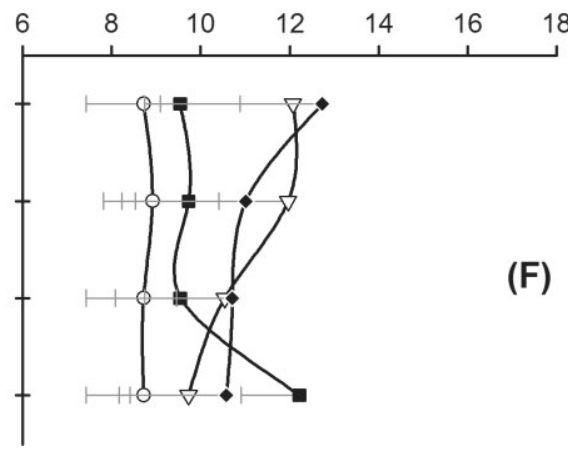

Figure 4: Soil S fractions concentration and distribution $\left(A=\right.$ total $S ; B=$ organic $S ; C=$ residual $S ; D=$ inorganic $S O_{4}-S$; $E=$ ester-bonded $S$; and $\mathrm{F}=\mathrm{C}$-bonded $\mathrm{S}$ ) in a pastureland soil profile under different $\mathrm{N}$ - and $\mathrm{S}$-fertilization regimens during the 2 y period. Nitrogen and $\mathrm{S}$ rates are expressed in $\mathrm{kg} \mathrm{ha}^{-1} \mathrm{y}^{-1}$. Error bars represent standard errors of the mean.

processes in the presence of available N, C, and S. Accordingly, we hypothesize that the increases in the residual $S$ in the fertilized plots can be attributed to $\mathrm{N}$ and $\mathrm{S}$ inputs (fertilizers), C source (enhanced plant growth and root residues and exudates), and/or transformations of other $\mathrm{S}$ organic fractions to residual $S$ forms (Maynard et al., 1985). The incorporation of inorganic $\mathrm{SO}_{4}-\mathrm{S}$ in the organic residual $\mathrm{S}$ fraction represents an important process in these soil and climate environments because it reduces the chance of $S$ losses by leaching.

Unlike residual S, organic C-bonded S reduced by Raney-Ni alloy and denominated here as $\mathrm{C}$-bonded $\mathrm{S}$ was reduced in all treatments (Fig. 3). The greatest decrease in C-bonded S stocks was found in the unfertilized plots. Previous studies had suggested that changes in the $\mathrm{C}$-bonded $\mathrm{S}$ content of soil are related to alterations in the microbial biomass (Castellano and Dick, 1988) because a majority of the $S$ in microorganisms occurs as C-bonded S in the cystine, cysteine, and methionine amino acids (Freney, 1986). Numerous studies have investigated the dynamics of soil organic $S$ fractions using the concept of $\mathrm{C}$-bonded $\mathrm{S}$ as the sum of $\mathrm{C}$-bonded $\mathrm{S}$ reducible by Raney-Ni plus residual S (McLachlan and De Marco, 1975; Nguyen and Goh, 1992; Solomon et al., 2001). For example, Solomon et al. (2001) investigated the influence of land-use changes on the S amounts and forms in the subhumid highlands soils of southern Ethiopian and reported that C-bonded S accounted for $73 \%$ to $88 \%$ of the total S deple- 


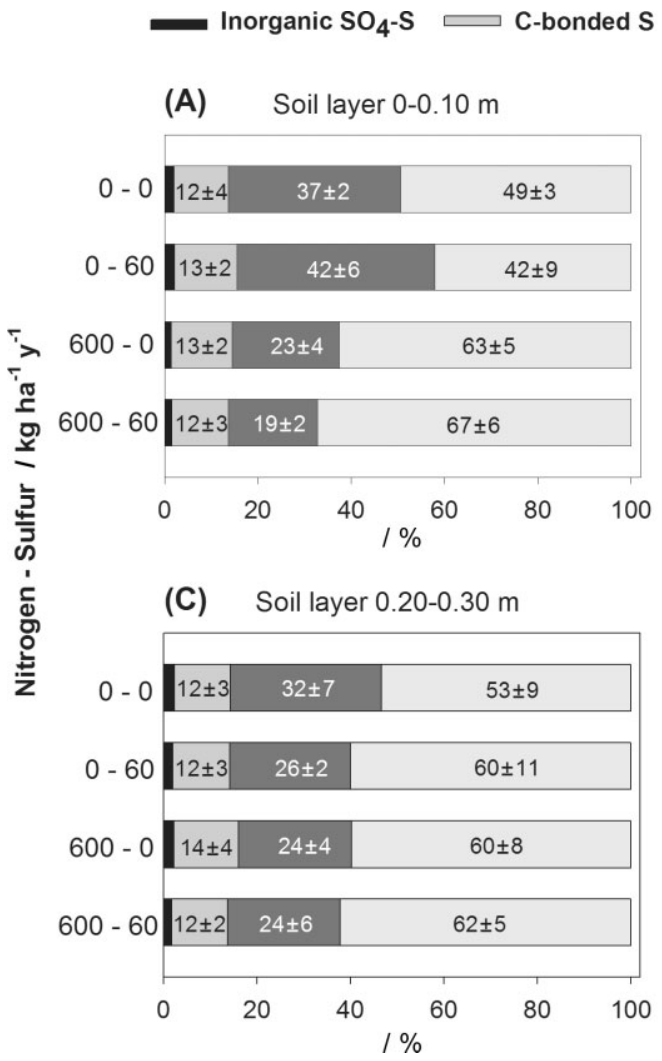

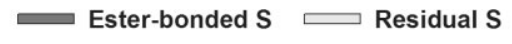

(B) Soil layer $0.10-0.20 \mathrm{~m}$

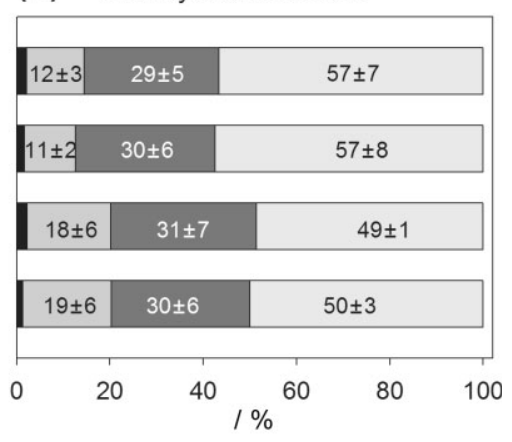

(D) Soil layer $0.30-0.40 \mathrm{~m}$

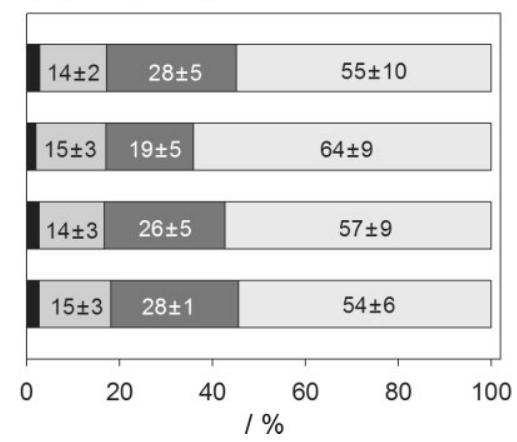

Figure 5: Contribution of different $\mathrm{S}$ fractions to the total $S$ in soil-profile layers $(A=0-0.10 \mathrm{~m} ; B=0.10-0.20 \mathrm{~m}$; $\mathrm{C}=0.20-0.30 \mathrm{~m}$; and $\mathrm{D}=0.30-0.40 \mathrm{~m}$ ) of a pastureland amended with $\mathrm{N}$ and $\mathrm{S}$ fertilizers during the 2 y period. Mean \pm standard error of the mean. tions in cultivated fields that had not been fertilized for a period of 25-30 y. Similarly, Nguyen and Goh (1992) studied grazed pastures in New Zealand that had been fertilized annually with superphosphate for $>15 \mathrm{y}$ and reported that the application of S-containing fertilizers at rates of 188 or $376 \mathrm{~kg}$ ha-1 $\mathrm{y}^{-1}$ significantly increased the accumulation of $\mathrm{C}$-bonded $\mathrm{S}$. However, other studies focused on detailed characterization of soil $\mathrm{S}$ distribution across various soil pools have suggested that the C-bonded S reducible by Raney-Ni alloy fraction is relatively stable and that more pronounced changes are expected to occur in the residual $\mathrm{S}$ fraction (Castellano and Dick, 1988; Hu et al., 2002; De Bona and Monteiro, 2010).

In addition to the impacts on forage yield, $\mathrm{N}$ fertilization also influenced the dynamics and distribution of the ester-bonded $S$ fraction in the soil profile (Figs. 4E and 5). The esterbonded $S$ concentration in the topsoil layer $(0-0.10 \mathrm{~m})$ and stock throughout the soil profile $(0-0.40 \mathrm{~m})$ decreased after $2 \mathrm{y}$ of repeated $\mathrm{N}$ application (Fig. 3). We propose the following hypotheses to explain these ester-bonded $S$ responses to $\mathrm{N}$ fertilization: (1) as $\mathrm{N}$ improved plant growth and inorganic $\mathrm{SO}_{4}$-S extraction by plants (Fig. 2), the ester-bonded S fraction was susceptible to mineralization via soil-enzymatic processes; and (2) enhanced plant growth in response to $\mathrm{N}$ input may have favored the transformation of ester-bonded $S$ to residual S. Studies have reported that lowering the concentration of inorganic $\mathrm{SO}_{4}$-S in the soil solution by intense plant growth stimulates the enzymatic hydrolysis (sulfohydrolases) of ester-bonded S (Maynard et al., 1985). Maynard et al. (1985) reported the redistribution of $35 \mathrm{~S}$ from HI-reducible (ester-bonded S) to C-bonded (residual S) forms of soil S in studies carried out in the presence of growing plants. Supporting this hypothesis, our data show that residual $S$ increases in the plots fertilized only with $\mathrm{N}$, whereas the esterbonded $S$ is reduced (Fig. 3). Moreover, we expect that both hypotheses are likely to explain the changes in the esterbonded $\mathrm{S}$ in response to the $\mathrm{N}$ additions in our experimental system.

\section{Conclusions}

In tropical pasture soils sustaining Brachiaria decumbens, the soil S pool consists primarily of organic S. Plant-available inorganic $\mathrm{SO}_{4}$-S is found in very low concentrations, even in areas receiving $S$ fertilizer. Sulfur increased signal grass production only when $\mathrm{N}$ was applied in combination with $\mathrm{S}$ fertilizer. Forage production and $S$ accumulation in the plant tissues affected the dynamics of $S$ organic pools. Residual $S$, the largest $S$ organic pool, showed the most pronounced changes in response to $\mathrm{N}$ and $\mathrm{S}$ fertilization. Additional studies using modern techniques such as synchrotron-based XANES (X-ray absorption near-edge structure) spectroscopy are warranted to further investigate the chemical nature and role of the residual $S$ fraction on the sustainability of pasture systems in tropical soils.

\section{Acknowledgments}

We are grateful to The State of São Paulo Research Foundation (FAPESP) and The Brazilian National Council for Scientific and Technological Development (CNPq) for the research 
financial support and for providing scholarships to the authors.

\section{References}

Boletim 100 (1996): Recomendações de adubação e calagem para o estado de São Paulo. IAC, Campinas, Brazil.

Castellano, S. D., Dick, R. P. (1988): Distribution of sulfur fractions in soil as influenced by management of organic residues. Soil Sci. Soc. Am. J. 52, 1403-1407.

De Bona, F. D., Monteiro, F. A. (2010): Nitrogen and sulfur fertilization and dynamics in a Brazilian Entisol under pasture. Soil Sci. Soc. Am. J. 74, 1248-1258.

Freney, J. R. (1986): Forms and reactions of organic $S$ compounds in soil, in Tabatabai, M. A. (ed.): Sulfur in Agriculture. Agron. Monogr. 27, ASA/CSSA/SSSA, Madison, WI, USA, pp. 207-232.

Ghani, A., McLaren, R. G., Swift, R. S. (1993): The incorporation and transformations of $35 \mathrm{~S}$ in soil: effects of soil conditioning and glucose or sulphate additions. Soil Biol. Biochem. 25, 327-335.

Hu, Z., Yang, Z., Xu, C., Haneklaus, S., Cao, Z., Schnug, E. (2002): Effect of crop growth on the distribuition and mineralization of soil sulfur fractions in the rhizosphere. J. Plant Nutr. Soil Sci. 165, 249-254.

Johnson, C. M., Nishita, H. (1952): Micro-estimation of sulphur in plant materials, soils and irrigation waters. Anal. Chem. 24, 736-742.

Kalmbacher, R. S., Ezenwa, I. V., Arthington, J. D., Martin, F. G. (2005): Sulfur fertilization of Bahiagrass with varying levels of nitrogen fertilization on a Florida Spodosol. Agron. J. 97, 661-667.

Kertesz, M. A., Mirleau, P. (2004): The role of soil microbes in plant sulphur nutrition. J. Exp. Bot. 55, 1939-1945.

Kost, D., Cheng, L., Dick, W. A. (2008): Predicting plant sulfur deficiency in soils: results from Ohio. Biol. Fertil. Soils 44, 1091-1098.

Lisle, L., Lefroy, R., Anderson, G., Blair, G. (1994): Methods for the measurement of sulphur in plants and soil. Sulphur Agric. 14, 45-54.

Mathot, M., Mertens, J., Verlinden, G., Lambert, R. (2008): Positive effects of sulphur fertilisation on grasslands yields and quality in Belgium. Eur. J. Agron. 28, 655-658.

Maynard, D. G., Stewart, J. W. B., Bettany, J. R. (1985): The effects of plants on soil sulfur transformations. Soil Biol. Biochem. 17, 127-134.

McGill, W. B., Cole, C. V. (1981): Comparative aspects of cycling of organic C, N, S and P through soil organic matter. Geoderma 26, 267-286.

McLachlan, K. D., De Marco, D. G. (1975): Changes in soil sulphur fractions with fertilizer additions and cropping treatments. Aust. J. Soil Res. 13, 169-176.
Neptune, A. M. L., Tabatabai, M. A., Hanway, J. J. (1975): Sulfur fractions and carbon-nitrogen-phosphorus-sulfur relationships in some Brazilian and lowa soils. Soil Sci. Soc. Am. Proc. 39, 51-55.

Nguyen, C. (2003): Rhizodeposition of organic C by plants: mechanisms and controls. Agronomie 23, 375-396.

Nguyen, M. L., Goh, K. M. (1992): Status and distribution of soil sulphur fractions, total nitrogen and organic carbon in camp and non-camp soils of grazed pastures supplied with long-term superphosphate. Biol. Fertil. Soils 14, 181-190.

Prietzel, J., Thieme, J., Neuhäusler, U., Susini, J., Kögel-Knabner, I. (2003): Speciation of sulphur in soils and soil particles by X-ray spectromicroscopy. Eur. J. Soil Sci. 54, 423-433.

Salvagiotti, F., Castellarín, J. M., Miralles, D. J., Pedrol, H. M. (2009): Sulfur fertilization improves nitrogen use efficiency in wheat by increasing nitrogen uptake. Field Crop. Res. 113, 170-177.

Scherer, H. W. (2001): Sulphur in crop production - invited paper. Eur. J. Agron. 14, 81-111.

Soil Survey Staff (1999): Soil taxonomy. 2nd edn., NRCS-USDA Agric. Handb. 436, U.S. Gov. Print. Office, Washington, USA.

Solomon, D., Lehmann, J., Tekalign, M., Fritzsche, F., Zech, W. (2001): Sulfur fractions in particle-size separates of the sub-humid Ethiopian highlands as influenced by land-use changes. Geoderma 102, 41-59.

Stanko, K. M., Fitzgerald, J. W. (1990): Sulfur transformations in forest soils collected along an elevational gradient. Soil Biol. Biochem. 22, 213-216.

Stanko-Golden, K. M., Fitzgerald, J. W. (1991): Sulfur transformations and pool size in tropical forest soils. Soil Biol. Biochem. 23, 1053-1058.

Tabatabai, M. A. (1982): Sulfur, in Page, A. L. (ed.): Methods of Soil Analysis, Part 2, Chemical and Microbiological Properties. 2nd edn., Agron. Monogr. 9, ASA, Madison, WI, USA, pp. 501-538.

Tabatabai, M. A. (2005): Chemistry of Sulfur in Soils, in Tabatabai, M. A., Sparks, D. L. (eds.): Chemical Processes in Soils. Book Ser. 8, SSSA, Madison, pp. 193-226.

Tabatabai, M. A., Bremner, J. M. (1970): A simple method of determining total $S$ in plant materials. Agron. J. 62, 805-806.

Vannier, C., Guillet, B. (1994): Sulphur forms in the organic fractions of an upland forest soil (Mont Lozère, France). Soil Biol. Biochem. 26, 149-151.

Wang, S., Wang, Y., Schnug, E., Haneklaus, S., Fleckenstein, J. (2002): Effects of nitrogen and sulphur fertilization on oats yield, quality and digestibility and nitrogen and sulphur metabolism of sheep in the Inner Mongolia Steppes of China. Nutr. Cycl. Agroecosyst. 62, 195-202.

Yang, Z., Singh, B. R., Hansen, S., Hu, Z., Riley, H. (2007): Aggregate associated sulfur fractions in long-term (> 80 years) fertilized soils. Soil Sci. Soc. Am. J. 71, 163-170. 